\title{
Biztonsági kérdések a turizmusban, egy határ menti térség példáján keresztül
}

\author{
Szerzők: Ernszt Ildikó ${ }^{1}$ - Péter Erzsébet² - Keller Krisztina ${ }^{3}$ - Tóth-Kaszás Nikoletta ${ }^{4}$
}

Amennyiben túllépünk a biztonság klasszikus értelmezésén, ami a jogellenes cselekményektől való mentességet - jelen esetben elsôsorban a terrortámadásoktól való biztonságot - jelenti, meg kell említenünk a technikai értelemben vett biztonság számos elemét. A tágabb értelemben felfogott biztonsághoz tartozik többek között a környezet (épített és természeti), a fogyasztás, az egészség biztonsága is. De más oldalról is megközelithetjük a kérdést. Nemcsak a turisták biztonságát kell hangsúlyozni, amit folyamatosan szem elött tartunk, amikor ez a téma elótérbe kerül, hanem az is fontos, hogy a turizmus a turisztikai desztináció lakosai számára is biztonságos legyen. Mivel a biztonság sarkalatos kérdéssé vált, a biztonságos úti célok egyre népszerübbé válnak. Emellett erôsödik egy olyan trend is, ami a természetközeliséget, a nyugalmat preferálja a nyüzsgó nagyvárosok, a turistáktól hemzsegố nyaralóhelyek nyújtotta kínálattal szemben. A biztonság egyes vetületeivel foglalkozó vizsgálatunk fókuszában a Letenyei járás áll. Ezen vizsgálatban egy kérdőives kutatás keretében mértük fel, hogy a gazdasági válság és a terrorfenyegetettség hatásai mennyire érezhetőek országosan, illetve a vizsgált járás vonatkozásában. Továbbá feltártuk azt is, hogy a megkérdezettek mennyire érzik biztonságosnak az online fizetést a turisztikai jellegú foglalásaiknál, kifizetéseiknél, illetve hogy szükségesnek érzik-e a külföldre utazók, hogy utasbiztositást kössenek, és ha igen, mindezt hány nappal korábban teszik.

Kulcsszavak: turizmus, biztonság, online foglalás, biztosítás.

\section{Bevezetés}

Napjainkban egyre fontosabb kérdés a biztonság, amely a turizmusban is szerepet játszik. Megváltoztak a preferált turisztikai desztinációk, mivel számos ország turisztikai kereslete visszaesett a különböző fenyegetések vagy épp terrortámadások miatt, miközben új, biztonságosabbnak vélt területek forgalma fellendült.

A biztonság napjainkban olyan mértékben meghatározza egy már létező vagy akár egy potenciális turisztikai desztináció múködését, hogy a biztonságfaktorok egyúttal a turizmusipar alapfeltételeiként értelmezhetők. Az intézményesült fenyegetettség, a közegészségügyi helyzet és az életkörülmények azok a biztonságfaktorok, amelyek külön-külön vagy együttesen észlelt hiányosságai a

\footnotetext{
1 egyetemi docens, Pannon Egyetem Nagykanizsai Kampusz, ernszt.ildiko@uni-pen.hu

2 egyetemi docens, Pannon Egyetem Nagykanizsai Kampusz, peter.erzsebet@uni-pen.hu

3 egyetemi docens, Pannon Egyetem Nagykanizsai Kampusz, keller.krisztina@uni-pen.hu

4 egyetemi adjunktus, Pannon Egyetem Nagykanizsai Kampusz, kaszas.nikoletta@uni-pen.hu
}

turizmusipar kibontakozásának, a forgalom bővülésének folyamatos vagy időleges gátjává válhatnak (MICHALKÓ 2012).

Felértékelődött az, ha egy turisztikai desztináció biztonságos. A biztonság márkaépítő elem lehet, amit ki lehet, és ki is kell használni. Biztonság nélkül a tömegturizmus folyamatai az abban résztvevők számára nem értelmezhetôk (ZSARNOCZKY 2017). Ugyanakkor a biztonságnak számos aspektusa van. Sajnos a veszélyeztetett térségekben a helyiek is áldozatul eshetnek a megnövekedett búnözésnek. El kell viselniük, hogy megszúnik a nyugalom, amikor a tömegturizmus és annak minden negatív hozadéka átsöpör az adott helyen. Ki kell szolgálni a tömegek deviáns igényeit, a felszín alatt felütheti fejét a prostitúció, a gyermekkereskedelem, a kényszermunka, a mindezekre építő szervezett búnözés. A legsérülékenyebb csoportok így fokozott veszélynek vannak kitéve. A gyermekek, nők, fiatalok válnak a legkönnyebben áldozattá, és a kényszermunka hálójában vergődve megjelennek a „szexpiacon”. Így kiemelkedően fontos, hogy minél gyakrabban szót ejtsünk arról, hogy az utazási piac csillogó világának mélyén milyen sötét titkok rejlenek. Azonban a fenti negatív forgatókönyv természetesen nem törvényszerú, és számos olyan desztináció vagy formálódó jövőbeli desztináció is 
létezik, ahol ezek a jelenségek nem ütötték fel a fejüket, és a béke szigeteként jelennek meg.

A turizmus számtalan meghatározásának lényege a szolgáltatások igénybevételével párosuló átmeneti környezetváltozás, amelynek legfóbb célja az élményszerzés. A turizmusbiztonság a turizmus piacának eredményes múködését és fejlődését gátló veszélyforrások hiánya. Másként fogalmazva a turizmusbiztonság az utazásból és az átmeneti tartózkodásból fakadó, az utazót és a desztinációt egyaránt fenyegető kockázatok csökkentése, illetve kizárása (MICHALKÓ 2012). A turizmusbiztonságot veszélyeztető faktorok sok esetben a kulturális sokk lehetséges kialakulásához és fenntartásához is hozzájárulnak (MALOTA 2011, BOGÁROMI MALOTA 2017).

Empirikus kutatásunk helyszíne, a Letenyei járás, Magyarország délnyugati szegletében fekszik, a horvát és a szlovén határ mellett. Aprófalvas jellege miatt magas településsúrúség és kis lélekszám jellemzi. A falvakra komoly veszélyt jelent az elnéptelenedés, továbbá a munkanélküliségi ráta Zala megyén belül Letenye térségében a legmagasabb. A vizsgált járás idegenforgalma kevésbé jelentôs, inkább több lokális attrakció laza halmazának, mintsem ezek szoros együttmúködésének tekinthető. Igazán domináns turisztikai mágnes sem található a térségben. A kulturális értékeit számba véve kijelenthetjük, hogy meglehetősen kevés nagy jelentőséggel bíró épített örökséget óriz. NÉMETH $(2008,2017)$ szerint a vidékies térségek formálódó új arculata számos esetben új szerepeket kínál, új feladatokat vetít előre, és innovatív megközelítést követel meg.

Meglehetősen nagy az átutazó forgalom a járásban, mivel Letenye város az ország délnyugati kapuja Horvátország felé. Az ottani határátkeló jelentős személy- és teherforgalmat bonyolít le, mely 0-24 óráig nyitva áll az átkelők számára. A személyforgalom szempontjából legkeresettebb úti cél az Adriai tengerpart, mely Letenyétól személyautóval 3 órán belül elérhetô. A határt személyi igazolvánnyal is át lehet lépni, ami még inkább megkönnyíti az átjárást.

$\mathrm{Az}$ elmúlt 10 év adatait vizsgálva láthatjuk (KSH 2017), hogy a járás turisztikai vendégforgalmát elsősorban a belföldi utazók teszik ki. Ezen utazók száma meglehetósen alacsony értéket mutatott 2014-ig, azonban a 2015-ös évben több, mint 300\%-os növekedés volt tapasztalható. Ez a növekedés 2016-ra visszaesett ugyan, de a korábbi évekhez képest még így is csaknem kétszeres vendégforgalmat jelent. 2017 harmadik negyedévének adatai alapján elmondható, hogy ezen idószak is sikeres lesz a térség turisztikai szolgáltatói számára, ugyanis több, mint 6000 fő́t regisztráltak a kereskedelmi szálláshelyeken 2017. január és szeptember hónapok között. A kiemelkedő időszak értelemszerúen július-augusztus volt, amely a fürdő nyitvatartásával is összecseng.

Jelen tanulmányban először egy online kérdőíves kutatás eredményeit kívánjuk bemutatni, amelyet a magyar lakosság utazási szokásainak felmérése céljából végeztünk el, különös tekintettel a biztonsággal kapcsolatos attitúdökre. Emellett megvizsgáltuk, hogy egy konkrét járásba, vagyis a Letenyei térségbe utazók utazási szokásai hogyan alakulnak, és hogy biztonsági szempontból milyennek értékelik a megkérdezettek magát a térséget.

\section{Módszertan}

A térség ismertségének feltárása, valamint a lakosság utazási szokásainak felmérése céljából kvantitatív kutatáson belül két omnibusz kutatást bonyolítottunk le. Az online kérdôívet 2017. október-november hónapokban tölthették ki a válaszadók, aminek eredményeként 198 értelmezhetô kérdőívet kaptunk az országos lekérdezés során. A kiválasztás EPSEM minta alapján történt. Szintén kérdőíves megkérdezés segítségével elégedettségi felmérést is végeztünk azon turisták körében, akik a Letenyei járásba látogattak, mely esetben a kérdốvet a térségi szolgáltatók bevonásával juttattuk el a célcsoporthoz, ahol szisztematikus kiválasztás során minden 5 . turista véleményét dolgozza fel jelen kutatás. Összesen 264 fó osztotta meg velünk a véleményét. Emellett áttekintettük az egyes potenciális fejlesztési irányokat megjelenítő turisztikai ágazatokra vonatkozó szakirodalmat is. A kínálat oldali elemzés keretein belül keresztmetszeti vizsgálatot végeztünk (MOLNÁR 2015, NAGY et al. 2006). A kvalitatív vizsgálat során Letenyei járásban múködő 13 turisztikai szolgáltatóval készítettünk strukturált interjút, amelynek eredményeit a kapcsolódó témaköröknél tüntetjük fel. A mintavételezés hólabda módszerrel készült.

\section{Gazdasági válság hatásai az utazási döntésekre}

A biztonságnak számos aspektusáról beszélhetünk, nem kizárólag a fizikai veszélyt értjük ez alatt. Fontos kérdés például az anyagi biztonság is. Sokak számára talán kétséges lehet, hogy egy tíz évvel ezelőtti válság hatásai érződnek-e még a mai turisztikai mutatószámokban, kutatócsoportunk azonban fontosnak tartotta ennek feltárását is, hiszen a válság idején keletkező tartozások vagy megnövekvó hitelterhek közel egy évtizeddel a válság után is nyomot hagyhatnak a családok üdülési szokásain. 
A 2008-ban kezdődő gazdasági válság jelentős visszaesést eredményezett a nemzetközi turizmus terén, azonban a hatásai régiónként eltérô mértéket mutattak. 2009 végén már határozottan érezhetó fellendülés jelent meg a világgazdaságban, de a területi egyenlótlenségek még mindig szembetúnőek voltak.

Érdekes kérdés, hogy a válság hatására az egyes iparágak és piacok hogyan változtak meg, mely kapcsán nem elhanyagolható, hogy sok szervezet, amelyik visszafogta marketingköltségeit, hátrányba került azon versenytársakkal szemben, akik ezt nem tették, mivel kevésbé váltak láthatóvá piacaik számára. Ez a tendencia a turizmushoz kapcsolódóan is megmutatkozik (BAUER et al. 2012).

A gazdasági válság ugyan visszavetette a turizmus folyamatos növekedését és bővülését, de ismételten beigazolódott, hogy az iparág szembeszáll a negatív hatásokkal, és 2010-től kezdődően folyamatos növekedést produkál. Az utazások mindennapjaink elválaszthatatlan részévé váltak (MAGYAR TURIZMUS ZRT. 2014). A válságnak pozitív hozadéka is volt, mivel - a luxusutazásoktól eltekintve - a külföldi nyaralásokra kevesebb pénz jutott, így megerósödött a belföldi turizmus. Ezt támasztja alá kutatásában BÍRÓ (2009), miszerint az utazások kapcsán átrendeződésnek lehettünk tanúi, amely sok esetben mind a mai napig érezhetơ: népszerúbbekké váltak a belföldi és a közelebbi úti célok, illetve rövidebb idóre utaznak el a turisták. Mivel a szolgáltatások szintjével, minőségével szembeni elvárások egyre magasabbak, a „kitúnó szolgáltatást, ellátást kedvezó árakon" szlogen nagyon erôteljesen érvényesül.

A jelenlegi adatok szerint szárnyal a turizmus, és soha nem látott fejlődés, bővülés mutatkozik. Az Európai Turisztikai Bizottság (European Travel Commission) legfrissebb, 2017-es évre vonatkozó elemzései azt mutatják, hogy rekordmértékú, mintegy 8\%-os növekedés tapasztalható az Európába érkezô nemzetközi utasforgalom vonatkozásában. Valamennyi európai országban érzékelhetó volt ez a folyamat, az országok felében a növekedés a 10\%-ot is meghaladta (ETC 2018). Magyarországon a többnapos belföldi utazások száma 2016-ban némileg csökkent azt követően, hogy az azt megelőző két évben (2014-2015) emelkedést tapasztaltak a szakemberek. A 2015-ös adatokhoz képest növekedés mutatkozott a magyarok külföldi utazásainak mértékében (MTÜ 2017).

$\mathrm{Az}$ empirikus kutatás eredményei szerint az országos válaszokból az derül ki, hogy a megkérdezettek 36\%-a kedvezóbb finanszírozású megoldást keres, $29 \%$ pedig olcsóbb nyaralást választ, ami többnyire hosszú hétvégéket és a nyári nyaralás esetén 4-5 napos utazást jelent (1. táblázat).
1. táblázat A gazdasági válság hatása a nyaralási döntésre

\begin{tabular}{|l|c|c|}
\hline & $\begin{array}{c}\text { Országos } \\
\text { válaszok } \\
\text { megoszlása }\end{array}$ & $\begin{array}{c}\text { Letenyei } \\
\text { járás } \\
\text { válaszainak } \\
\text { megoszlása }\end{array}$ \\
\hline olcsóbb megoldást keresek & $36 \%$ & $16 \%$ \\
\hline $\begin{array}{l}\text { rövidebb nyaralást } \\
\text { választok }\end{array}$ & $29 \%$ & $16 \%$ \\
\hline $\begin{array}{l}\text { inkább belföldi nyaralást } \\
\text { választok }\end{array}$ & $26 \%$ & $20 \%$ \\
\hline $\begin{array}{l}\text { kevesebbszer megyek } \\
\text { pihenni }\end{array}$ & $26 \%$ & $16 \%$ \\
\hline $\begin{array}{l}\text { egyáltalán nem } \\
\text { befolyásolja }\end{array}$ & $25 \%$ & $26 \%$ \\
\hline $\begin{array}{l}\text { kevesebb szolgáltatást, } \\
\text { szórakozási lehetőséget } \\
\text { veszek igénybe }\end{array}$ & $16 \%$ & $7 \%$ \\
\hline $\begin{array}{l}\text { egyáltalán nem megyek } \\
\text { nyaralni }\end{array}$ & $5 \%$ & $1 \%$ \\
\hline
\end{tabular}

Forrás: saját szerkesztés

Azon válaszadók, akik a lekérdezés ideje alatt a letenyei térségben töltötték pihenésüket, 25\%-ban egyáltalán nem érzik már a válság hatásait, vagy legalábbis ez nem befolyásolja döntésüket. A kutatásba bevont alanyok 20\%-a a belföldi nyaralásokat preferálja.

A kvalitatív kutatás eredménye szerint a 2008ban kezdôdố pénzügyi válság hatását a Letenyei járásban felkeresett szolgáltatók (13 fó) egyetlen kivételtól eltekintve nem érezték, helyette más negatív hatásokról számoltak be. Ezek közé tartozik a szállásfoglalási portálok (például booking.com) megjelenése, vagy a fesztiválok, mint új, fiataloknak szóló programok, elszívó hatása.

\section{Különféle fenyegetettségek hatása a turizmusra}

A terrorcselekmények, melyek az elmúlt időszakban egyre gyakrabban vettek célba turisztikai szempontból frekventált területeket, nagyon súlyos hatással voltak az érintett országok turizmusára. Jelentôs visszaesést szenvedtek el olyan, magyarok körében is népszerú célpontok, mint Tunézia, Törökország, Egyiptom, Belgium, Franciaország vagy Marokkó. Érdekes, hogy az egyes országok lakóinak utazási döntéseit eltérő mértékben befolyásolták a biztonsági kérdések. A terrorfenyegetettség leginkább az ázsiai és a kelet-európai utazók utazási döntéseire volt hatással, legkevésbé pedig a skandináv, holland és amerikai turisták utazási döntéseiben éreztette a hatását. A különböző tár- 
sadalmi csoportok is más utazói attitúddel viseltetnek a biztonsági kérdések tekintetében: leginkább a gyermekes családok reagáltak érzékenyen, a fiatalabb, illetve egyedülálló utazókat nem kimondottan érdekelte ez a kérdés (TURIZMUS ONLINE 2016). A World Travel and Tourism Council (WTTC, Utazási és Turisztikai Világtanács) által készített kutatás arra az érdekes paradoxonra hívja fel a figyelmet, hogy a terrorcselekményeket követően a turizmus viszonylag rövid időn belül, 13 hónap alatt, képes elérni a biztonságérzetet megrengetó cselekményeket megelőző szintet. Egyéb problémák vonatkozásában ugyanezt a „regenerálódási időt” vizsgálták, és kiderült, hogy „betegség, járvány után 21, környezeti katasztrófát követóen 24, politikai zavargásokat követően pedig 27 hónapnyi időre van szükség a felépüléshez" (ZILLMAN 2015, idézi: ERNSZT 2016:99).

A legfrissebb elemzés arra mutat rá, hogy a terrortámadásokat követően jelentős mértékú növekedést tudtak felmutatni a fent említett desztinációk a tavalyi, 2017-es évben. Így Törökország rekord mértékú, 28\%-os növekedést élt meg, ami a legnagyobb mértékú növekedés az európai országok között (ETC 2018).

A terrorcselekmények gazdasági hatásaival is számolni kell: az utazók jelentős hányada lemondja a foglalásait a kockázatosnak tekintett turistaparadicsomokba, ami nagy veszteséget okoz a teljes turisztikai iparágnak.

A terrorizmussal összefüggő kérdésekben a magyar lakosság utazási szokásait vizsgáló kérdôívünk válaszadói közül többen rövidebb nyaralást választanak, vagy épp belföldön pihennek, mivel ez növeli a biztonságérzetüket. Érdekes volt, hogy bár a lakosok láthatóan tartanak a terrorizmustól, a válaszadók 94\%-a nem mondta le semmilyen programját a terrorveszély miatt. Csupán 1-1 válaszadó nyilatkozott úgy, hogy biztonsága érdekében lemondott valamilyen múvészeti, tudományos, sport, kereskedelmi, társadalmi, politikai vagy egyházi jellegú programot. A Letenyei járásba látogatók körében is kíváncsiak voltunk arra, hogy a válaszadók változtattak-e a programjukon bármikor terrorfenyegetettség miatt. Hasonló eredményt kaptunk ebben az esetben is: elmondhatjuk, hogy szerencsére ez nem igazán jellemzó, a magyarok $85 \%$-a azt válaszolta, hogy soha nem fordult elő ilyesmi.

A Letenyei járás turisztikai szolgáltatóival végzett strukturált interjúk arról számoltak be, hogy a terrorfenyegetettség nem érződik a desztinációban. A válaszadók többsége úgy vélte, hogy „a turisták nem amiatt jönnek, mert félnek más országokban, városokban (például Párizsban) attól, hogy történik velük valami, hanem azért jönnek, mert szeretnének ellátogatni hozzánk, szeretnének részt venni a programjainkon" (interjúalanyok).

\section{Turizmushoz köthetó kockázati tényezók}

\subsection{BIZTOSÍTÁSOK LÉTJOGOSULTSÁGA}

A kockázatok csökkenthetők, amennyiben valaki biztosítást köt a nyaralás előtt. Ez különösen a külföldre történó utazások alkalmával bír nagy jelentôséggel. A biztosítók általában három különböző terméket kínálnak, olcsó, közepes és kiemelt kategóriában. A legfontosabb, hogy az ajánlatok tartalmazzák a számunkra fontos szolgáltatásokat és biztosítási összegeket. A szolgáltatásukban már megfelelő termékek között pedig ár-érték alapján választunk. Ezekhez ma már hatékony segítséget kaphatunk az interneten múködő összehasonlító portálokon, ahol nem csak választani, hanem szerződést kötni is tudunk.

Évente átlagosan 10-16 millió magyar utazóról beszélhetünk, ezen utazók mintegy 40\%-a köt utazási biztosítást. Főszezonnak a nyári és a téli hónapok mondhatók, de évközben is egyre többen utaznak már külföldre (PÉTER 2017).

Míg korábban elsősorban utazási irodákban kötöttek biztosítást, ma már egyre többen élnek az internet kínálta lehetôségekkel. Az interneten kötött utasbiztosítások száma az elmúlt három évben évről-évre nőtt. Az online felületen elérhető szolgáltatókkal - akiknél minden biztosító ajánlata egy helyen megtalálható - történő szerződéskötésnek számos előnye van. Először is nem kell sehová sem elmennünk, nem kell sorban állnunk, és nem kell az ügyfélfogadási időhöz alkalmazkodnunk (VASS 2008). Az utazási szolgáltatásokra, illetve csomagra vonatkozó szabályozások a 2018. július 1-jétől hatályba lépő 472/2017. (XII. 28.) Kormányrendelettel ${ }^{5}$, fóként az utazásszervezókre vonatkozóan, változnak. A turisztikai szektor szereplőinek feladata, hogy tudatosan fejlesszék képességeiket a turizmust érintő új típusú, XXI. századi kihívások (terrorizmus, regionális konfliktusok, instabil régiók, szervezett bû́nözés, szélsőséges szerveződések, globális éghajlat- és környezetváltozás, természeti és ipari katasztrófák, egészségügyi veszélyforrások) kockázatainak felismerése és kezelése, illetve a turizmusbiztonság megteremtése, fenntartása és sikeres kommunikációja tekintetében.

A mai világban a lakossági és üzleti utazók vannak leginkább kitéve annak, hogy olyan hely-

5 472/2017. (XII. 28.) Korm. rendelet Az utazási szolgáltatásokra vonatkozó szerződésekről, különösen az utazási csomagra és az utazási szolgáltatásegyüttesre vonatkozó szerződésekről. Frissítve: 2018. május 15. 17:44. Hatály: közlönyállapot (2017. XII. 28.). 
re utazzanak, ahol terrorcselekmény következhet be. Szerencsére Magyarországon a terrorveszély szintje alacsony. A terroristák kedvelt célpontjai a turistaparadicsomok, hiszen az ezeken a helyszíneken elkövetett cselekménnyel rendkívüli félelmet képesek kelteni, és médiafigyelmet elérni.

$\mathrm{Az}$ empirikus kutatásunk eredményei alapján az online (országos) válaszadók 47,4\%-a köt mindenképpen biztosítást külföldi utazás előtt (1. ábra). A válaszadók 13,3\%-a nyilatkozott úgy, hogy nem tartja fontosnak biztosítás kötését. Nekik feltehetően nem voltak még negatív tapasztalataik ezen a téren, s nem szorultak még rá káreseménnyel kapcsolatos szolgáltatás igénybevételére. Nem gondolják úgy, hogy velük is történhet bármi, amihez orvosi segítséget kell igénybe venni. Létezik alternatív megoldás, amennyiben valaki nem szeretne utasbiztosítást kötni. Ilyen például a bankkártyához kapcsolódó automatikus utasbiztosítás, amit jellemzóen a drágább kártyákhoz adnak a bankok, vagyis érdemes utánanézni a legkedvezőbb feltételeknek. Ez a megoldás csupán a kártyabirtokosnak nyújt biztosítást, a hozzátartozóknak, gyerekeknek nem.

1. ábra

Utasbiztosítás kötéséhez kapcsolódó válaszok megoszlása

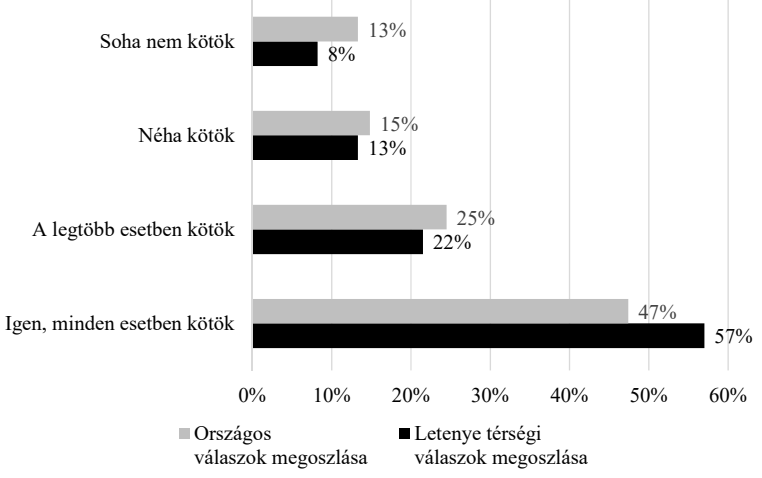

Forrás: saját szerkesztés

A letenyei térségbe utazók körében végzett felmérés szerint a magyarok a legtöbb esetben kötnek (57\% minden esetben, további 21,5\% a legtöbb esetben) utasbiztosítást külföldi utazásaik előtt. Mindössze $8 \%$ nyilatkozott úgy, hogy soha nem köt utasbiztosítást.

Külföldi utazás előtt érdemes megnézni, mely állam milyen kockázati besorolás alá tartozik. Értelemszerúen nem minden ország ugyanolyan kockázatú, Európa e tekintetben egységes, nincs a többinél kockázatosabb vagy biztonságosabb besorolású állam.
A különböző országokba történő beutazás általános feltételeiről a Külgazdasági és Külügyminisztérium, valamint az adott országokba akkreditált külképviseletek minél körültekintőbben igyekeznek tájékozódni, illetve a mindenkori rendelkezésre álló információk alapján tájékoztatást nyújtani. Ugyanakkor a beutazási, tartózkodási feltételekre vonatkozó jogi szabályozás az egyes országok tekintetében bármikor változhat, melyről a Külgazdasági és Külügyminisztérium nem minden esetben kap tájékoztatást.

Érdemes ellenőrizni az utazás előtt, hogy az útlevél vagy az utazáshoz használt okmány érvényes-e, szükséges-e és amennyiben igen, rendelkezik-e megfelelő vízummal a cél-, illetve tranzit országokba. Egyes országok esetében az útlevélnek a belépés idejétől számítva legalább 6 hónapig érvényesnek kell lennie. Ellenórizni kell az adott ország részletes beutazási feltételeit a minisztérium, illetve az adott ország hivatalos honlapján (például külügyminisztérium, külképviselet) (KONZULI SZOLGÁLAT 2018).

\subsection{ONLINE FOGLALÁSI ÉS VÁSÁRLÁSI SZOKÁSOK KOCKÁZATAI}

Az informatikai biztonság egy turizmust érintő aspektusát megvizsgálva a nyaralások lefoglalására is rákérdeztünk az országos kutatás során. Mindezzel célunk volt feltárni, hogy a kitöltók mely foglalási formában bíznak meg inkább, s melyik az, amelyet nem részesítenek előnyben.

A visszajelzések azt mutatják, hogy a szállásközvetítő oldalak a legnépszerúbbek (országos adat 35,9\%, térségi adat 26,2\%), amelyet a személyes, e-mailen történó foglalás követ (2. ábra). A többi foglalási forma jelentősen elmarad ezen eredményektől. Látható, hogy sem az utazási irodák, sem a kuponos oldalak vagy egyéb utazási oldalak nem bírnak jelentős aránnyal.

\section{Online foglalási szokások megoszlása}

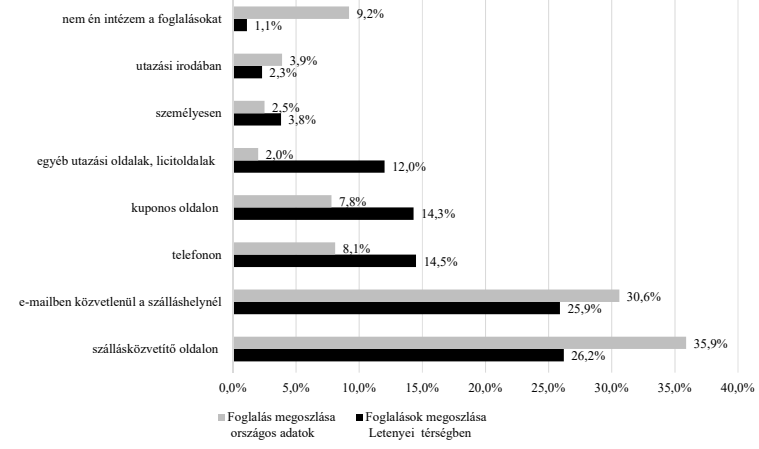

Forrás: saját szerkesztés 
A webes vásárlás legjelentősebb előírásait a fogyasztó és a vállalkozás közötti szerződések részletes szabályairól szóló 45/2014. (II. 26.) Kormányrendelet $^{6}$ tartalmazza. Ahogy a mindennapi élet részévé vált az online világ, a turizmusra gyakorolt hatásai is egyre jelentősebbek lettek. Összességében elmondható, hogy az utazási piacon a mobil, a közösségi keresés és a helyben szolgáltatott tartalmak a kulcstényezők.

Egy országos jelentés szerint elmondható, hogy a foglalások $46 \%$-a már online foglaló oldalakon történik, a második legnépszerúbbek az utazási irodák oldalai $21 \%-k a l$. Az online foglalásokat befolyásoló tényezők közt első helyen szerepel az olcsóság, mind a nyaralók (75\%), mind az üzleti utazók számára (64\%), valamint az egyszerúség és a gyorsaság. A válaszadók 66\%-a igényli az ár-összehasonlítás lehetôségét is (MAGYAR TURIZMUS ZRT. 2012).

$\mathrm{Az}$ internetes vásárlások egyre népszerúbbek lesznek nem csak az utazás, hanem egyéb más területen is. Megvizsgáltuk tehát azt is, hogy a megkérdezettek jellemzően mely utazásokhoz, nyaralásokhoz kapcsolódó terméket és szolgáltatást vásárolnak az interneten. Egyértelmúen a szálláshely volt a leginkább említésre került tényező, vagyis a megkérdezettek 2/3-a foglalt már szállást online. Az országos válaszok szerint a megkérdezettek 35\%-a vett a programokhoz belépójegyet online, míg a térségi látogatók 14,8\%-a adta ezt a választ. Ezen kívül a válaszadók körében az utasbiztosítás és a menetjegyvásárlás dominál online formában (3. ábra). Így e térségi szolgáltatókat fel kell készíteni az elektronikus kereskedelemre.

3. ábra

Utazással kapcsolatos internetes vásárlásoknál előnyben részesített elemek

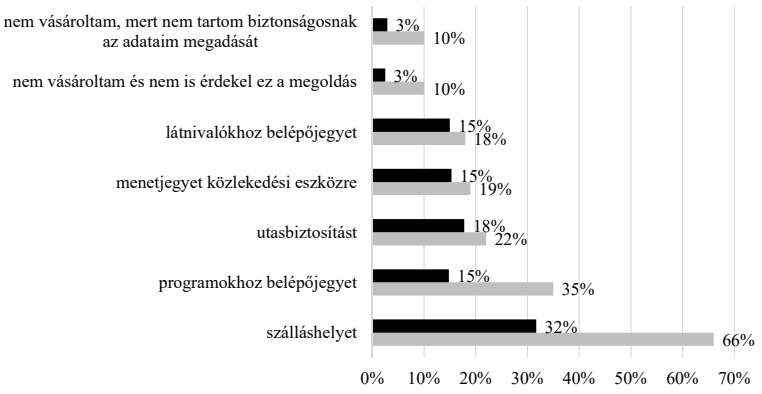

- Letenyei térség turistáinak véleménye alapján — \#rszágos válaszok megoszlása

Forrás: saját szerkesztés

645/2014. (II. 26.) Korm. rendelet a fogyasztó és a vállalkozás közötti szerződések részletes szabályairól, https://net. jogtar.hu/jogszabaly?docid=a1400045.kor， Letöltve: 2018 . június 22 .
A Letenyei térségbe látogató turisták esetében szintén rákérdeztünk az elektronikus vásárlás biztonságára. A legtöbb válaszadó szálláshelyet vásárolt már elektronikusan, hisz a turistákban alapvetóen nincs félelem vagy bizalmatlanság az elektronikus kereskedelemmel szemben.

\subsection{LAST MINUTE UTAK KOCKÁZATI ELEMEI}

Augusztus és szeptember a last minute utak szezonja, kalandvágyból vagy gazdasági megfontolásból egyre többen böngésznek az interneten kedvezményes ajánlatok után. A leszállított árért cserébe azonban több rugalmasságra és előkészületre van szükség.

Az ilyen utak előnye a kisebb-nagyobb árkedvezmény, és minél késóbb foglalunk, annál többet spórolhatunk az eredeti árhoz képest, miközben ugyanazt a szolgáltatást kapjuk. A last minute utak hátránya viszont, hogy valamilyen szinten biztosan kompromisszumot kell kötnünk. Például nem válogathatunk a szálláshelyek között, nem dönthetjük el, hogy félpanziót vagy teljes ellátást kérünk, nem lehet lemondani az utat, ha mégis közbejön valami, így a befizetett összeget nem térítik vissza.

A megkérdezett online válaszadók (2\%), illetve a térségben nyaralók (11,2\%) az utazás előtti héten foglalják le nyaralásukat. A letenyei térségben nyaralók 29,2\%-a azonban a last minute utakat preferálja. Legtöbben az 1-3 hónappal korábbi készülódést jelölték meg, az országos lekérdezés esetén 52\%, a térségben tartózkodó pihenóknél 46,7\% (4. ábra). Ma már egyre kevesebben tervezik meg a nyaralásukat teljes részletességgel.

\section{4. ábra \\ Utazási döntések meghozatalának időpontja (\%)}

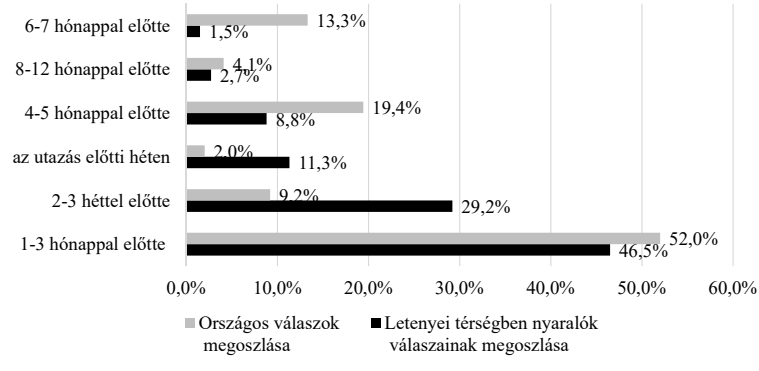

Forrás: saját szerkesztés

A felgyorsuló életritmus nem teszi lehetôvé, hogy sokat töprengjünk a lehetőségeken. Az utazási irodák a külföldi last minute és ultra last minute utakat általában 20-30\%-kal adják olcsóbban az eredeti árhoz képest, de természetesen ennek is megvannak a maga kockázatai. A belföldi vakációknál jobb 
a helyzet: aki sokat akar spórolni, nézzen körül a hotelkuponos oldalakon, ahol akár nagyobb kedvezménnyel is hozzájuthat a nyaralásához, igaz, fóleg kevésbé ismert vidéki panziókban és háromcsillagos hotelekben, ami az általunk vizsgált térség fő vonzerejét jelenti.

\section{Következtetések}

A béke, biztonság ígérete egy turisztikai desztináció vonatkozásában kiemelten fontos. Nemcsak a terrorcselekményektől való biztonság, hanem az egyéb búncselekmények létének hiánya is erős vonzerő lehet. Vannak olyan csoportok, akik számára esszenciális a nyugalom, ilyen különösen a gyermekekkel érkező családok és a számban egyre növekvő idősebb korosztály. Így azoknak a desztinációknak, amelyek ezt garantáltan nyújtani tudják, marketing célokra is ki kell használniuk ezt az adottságot. A kutatásokban részt vevő válaszadók 86\%-a, vagyis megközelítőleg egyharmada nyilatkozott úgy, hogy emiatt vagy rövidebb nyaralást választ, vagy inkább a hazai úti célokat választja nyaralása helyszínéül, ugyanakkor ez az esetek döntő többségében nem vezet programok lemondásához.

A kutatások meglepó eredményhez vezettek: akkor, amikor mind a globális, mind az európai szintû, sốt az országos statisztikák valamennyi adata egyértelmúen a turisztikai iparág robbanásszerú fejlődését hangsúlyozza, az általunk elvégzett kutatások azt mutatják, hogy a gazdasági válságnak mind a mai napig érezhető hatásai vannak némelyek számára, hiszen a válaszadók körülbelül harmada vagy olcsóbb vagy rövidebb nyaralást választ. Így annak ellenére, hogy a színvonal tekintetében egyre magasabb igényeket támasztanak a turisták a szolgáltatókkal szemben, még mindig van egy nem is elhanyagolható réteg, aki kénytelen olcsóbb vagy rövidebb ideig tartó nyaralásokat választani. Igy a szolgáltatóknak a két követelményt a lehetőségek szerint együtt kell érvényesíteni, hiszen az utazók elfogadható árak mellett kitúnô szolgáltatást, biztonságot és nyugalmat várnak el. Ezen a ponton pedig a vendégszeretet jelentőségét nem lehet eléggé hangsúlyozni. Ezzel akár ellensúlyozni lehet némileg, persze nem teljes mértékben, az esetlegesen kevesebb szolgáltatást vagy a "luxus" meglétének hiányát, illetve még szebbé, feledhetetlenebbé tenni a nyaralás élményét.

A biztosításról az emberek utazás előtt gyakran gondolkodnak úgy, hogy kidobott pénz. Amennyiben nem áll szándékunkban erre áldozni, célszerú kiváltani az európai egészségbiztosítási kártyát. Ennek birtokában gond nélkül igénybe lehet venni adott EGT ország egészségügyi rendszerét, amely kitûnő megoldás lehet az ott pihenni vágyóknak.

Az elutazásunk előtt érdemes fénymásolatokat készíteni az iratainkról, és utazás közben az eredeti iratoktól elkülönítve vagy digitális formában egy megbízható internetes honlapon, illetve e-mail fiókban tárolni óket.

Fontos továbbá tájékozódni a legközelebbi magyar nagykövetség, fókonzulátus vagy tiszteletbeli konzuli képviselet elhelyezkedéséről, elérhetőségeiről is még az elindulás előtt.

A globális trendek Magyarországon is láthatók. Nô a szép korúak aránya, akik speciális igényeket támasztanak a szálláshelyekkel szemben és erôsödnek az Y és Z generációs igények, amelyek kifejezetten a technológia által vezéreltek. A trendeket a szálláshely szolgáltatóknak és vendéglátóhelyeknek is követniük kell, ha nem szeretnének perifériára kerülni (BIRKNER - MAHR 2017). Becslések szerint 2020-ra az európai lakosság 44\%-a a digitális világ szülöttje lesz, amelyet az egyedi kommunikáció és a felfedezés vágya jellemez. A digitális csatornák egyre inkább a hétköznapi élet részévé váltak, amit a turizmusban dolgozó szakembereknek is fokozottan figyelemmel kell kísérni a biztosítások és az online foglalások körében is. Napjainkban az utazások előkészítésében az internet valóban kiemelkedően fontos szerepet játszik. Az utazni vágyók ma már online tájékozódnak a szálláshelyekről. Elsősorban az úgynevezett utazási gyújtőportálokat részesítik előnyben, ahol számtalan szálláshellyel találkozhatnak, melyek közül kedvükre válogathatnak. Döntésüket segíti, hogy ezen portálokon megtekinthetik a szálláshelyek értékelését, valamint az ott szereplő bejegyzések, kommentek szintén hozzájárulnak ahhoz, hogy a legjobb szálláshelyet választhassák. A hitelesség és a folyamatos online jelenlét a biztonság érzetét kelti a turizmusban.

A last minute utak foglalásakor egy kicsit jobban résen kell lennünk, hiszen ez is járhat kockázattal, ugyanis a csábító árak néha megtévesztőek, és egy kis utánajárással kiderül, hogy nem is lenne annyira olcsó a nyaralás. A megkérdezett online válaszadók (2\%), illetve a térségben nyaralók (11,2\%) az utazás előtti héten foglalják le nyaralásukat. A leggyakoribb buktató az, hogy a feltüntetett ár nem tartalmaz bizonyos szolgáltatásokat, például csak apró betúvel írják oda, hogy az utazást nekünk kell megoldani vagy például hogy a félpanzió pluszköltséget jelent. Amennyiben egzotikus úti célt választ az utazó, fontos az oltások, illetve a vízum időbeni beszerzése, oda kell figyelnie okmányai érvényességére, és a megfeleló biztosítás kötése is prioritást élvez a kockázatok kivédése érdekében. 


\section{Köszönetnyilvánítás}

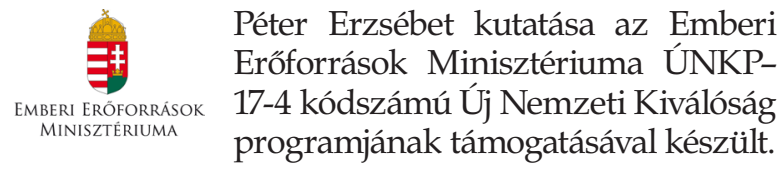

\section{Felhasznált irodalom}

BARNA K. - NAGY M. - MOLNÁR T. (2006): Egyszerúen statisztika 2. Feladatgyújtemény. Perfekt Kiadó, Kaposvár.

BAUER A. - CSEPETI Á. - GÁTI M. - MITEV A. (2012): A banki hitelfelvevők rejtett gazdaságból származó jövedelme: Marketing megközelítés és empirikus kísérlet a kockázatkezelés szolgálatában. Hitelintézeti Szemle. 11(4). pp. 298324.

BIRKNER Z. - MAHR T. (2017): Települések a digitális térben - negyedik dimenzió. Comitatus: Önkormányzati Szemle. 27(3). Különszám. pp. 3-10.

BÍRÓ G. (2009): A válság hatása a turisztikai piacokra, elórejelzések és intézkedések. http:// slideplayer.hu/slide/1903647/, Letöltve: 2018. február 14.

BOGÁROMI E. - MALOTA E. (2017): Kulturális sokk és fogyasztói akkulturáció - kétirányú, interdiszciplináris megközelítésben. Vezetéstudomány. 48(4). pp. 6-17.

ERNSZT, I. (2016): „Sullen Shadows under the Blue Sky"- Some Remarks about the Dark Side of Tourism and the International Legal Protection. In: Németh K. (szerk): I. Turizmus és Biztonság Nemzetközi Tudományos Konferencia. Pannon Egyetem Nagykanizsai Kampusz. Konferenciakötet. pp. 98-106.

ETC(EUROPEANTRAVELCOMMISSION) (2018): European Tourism in 2017, Trends \& Prospects (Q4/2017), Quarterly Report. Brussels, ETC Market INtelligence Report, February, 2018. http://etc-corporate.org/reports/europeantourism-2017-trends-and-prospects-(q4-2017)\#, Letöltve: 2018. március 3.

KONZULI SZOLGÁLAT (2018): Utazásra nem javasolt térségek. http://konzuliszolgalat. kormany.hu/utazasra-nem-javasolt-tersegek, Letöltve: 2018. május 16.

KSH (2017): Jelentés a turizmus és vendéglátás, 2016. évi teljesitményéról. http://www.ksh.hu/docs/ hun/xftp/idoszaki/jeltur/jeltur16.pdf, Letöltve: 2017. december 4.
MTÜ (MAGYAR TURISZTIKAI ÜGYNÖKSÉG) (2017): A magyar lakosság belföldi és külföldi utazásai 2016-ban - A KSH keresletfelmérésének adatai alapján. https://mtu.gov.hu/documents/ prod/magyarok_utazasai_2016__2.pdf, Letöltve: 2017. december 15.

MAGYAR TURIZMUS ZRT. (2012): Aktuális online turisztikai trendek. file:///C:/Users/user/ Downloads/online_trendek_2012_0309.pdf, Letöltve: 2018. február 22.

MAGYAR TURIZMUS ZRT. (2014): Utazások a válság után - az európai turizmus alakulása 2008 és 2013 között. Turizmus Bulletin. 15(2). pp. 53-57.

MALOTA E. (2011): Kultúrák és kommunikáció, Esettanulmányok és gyakorlatok. Oktatási anyag. Budapesti Corvinus Egyetem.

MICHALKÓ G. (2012): Turizmológia - Elméleti alapok. Akadémiai Kiadó, Budapest.

MOLNÁR T. (2015): Empirikus területi kutatások. Akadémiai Kiadó, Budapest.

NÉMETH, K. (2008): Decentralized power generation using solid biofuels. Acta Pericemonologica Debrecina. Tomus 3. pp. 117121.

NÉMETH K. (2017): Vidéki térségek innovációs kihívásai - Megújuló energia alternatívák. Pannon Egyetemi Kiadó, Veszprém. p. 95.

PÉTER E. (2017): Pörgés a turizmusban pihenési szokások átalakulása Zalában. In: Nagy Z. B. (szerk): LIX. Georgikon Napok. Pannon Egyetem Georgikon Kar, Keszthely. Konferenciakiadvány. Paper CD ROM.

TURIZMUS ONLINE (2016): Turizmus terrorizmus idején. http://turizmusonline.hu/kulfold/cikk/ turizmus_terrorizmus_idejen, Letöltve: 2018. február 19.

VASS L. (2008): A leggyakoribb kérdések az utasbiztosításokról. http://www.origo.hu/ utazas/20080214-utasbiztositas-sibiztositaskarterites-fedezet-tudnivalok.html?pIdx=1, Letöltve: 2018. február 20.

ZILLMANN, C. (2015): Terrorism's Effect on Tourism Doesn't Last Very Long. Fortune Magazine Travel Section. http://fortune. com/2015/11/30/terrorism-tourism-paris/, Letöltve: 2016. február 24.

ZSARNOCZKY, M. (2017): The Future of Sustainable Rural Tourism Development Impact of Climate Change. Annals of the Polish association of agricultural and agribusiness economists. 19(3). pp. 337-344. 